\title{
A Provocative Approach for Communication with Low-Proficient Children: Examining How the Interactive Role of Teachers and Children Changes
}

\author{
RESI DAMHUIS \\ Marnix Academie (University for Teacher Education), Utrecht, Netherlands \\ EEFJE VAN DER ZALM \\ Marnix Academie (University for Teacher Education), Utrecht, Netherlands
}

\begin{abstract}
Low-proficient children need to be engaged in high-quality oral interaction as soon as possible. Educational design research was conducted to discover elements of a provocative approach to enhance language and thought development of these children. These elements are presented and illustrated. Interactions were analysed in order to assess how teachers and children changed their role in the interactions, when teachers applied the approach. Results show that change is indeed possible, but not for everyone, nor to the same extent. Implications for teaching and professional learning initiatives are proposed.
\end{abstract}

a child has

Introduction

a hundred languages

a hundred hands

a hundred thoughts

a hundred ways of thinking

of playing, of speaking

Loris Malaguzzi-The 100 languages / No way. The 100 is there. (Meeuwig, Schepers \& van der Werf, 2007)

We were asked to draw on our research in the Netherlands with teachers of young children to provide recommendations to teachers participating in the NOW Play project. In response to this request, we present the results of our educational design research focusing on improving language learning opportunities for low-proficient young children. Working together with teachers we developed a didactical and pedagogical approach that provokes children to think and talk actively. We call it a provocative approach. We examined changes in teacher practice and the changes in young children's language that result from this new approach.

\section{Early Childhood Education in the Netherlands}

In the Netherlands, early childhood education and care involves children from 2.6 to 6 years of age. Until the age of four years, children go to preschool for two-to-four half days, although preschool is not compulsory. From the age of four, children attend 
kindergarten for five days of about five hours each. Kindergarten constitutes the first two grades of Dutch primary school.

Children who may be educationally disadvantaged are encouraged to participate in preschool. According to the national educational priority policy (OC\&W, 2013), children are considered educationally disadvantaged when they are from a non-Western background (i.e., working immigrants from Turkey and North Africa and refugees from Asia, the Middle East and Africa), or when their parents have a low educational level. Educational preschools - which use special educational programs to stimulate language, literacy and mathematics development-have been developed for these children. Research on the efficacy of these programmes has shown that the teacher is the crucial factor in early education (Haan, Elbers, Hoofs, \& Leseman, 2013). The amount of time the teacher spends with the children on language, literacy and mathematics activities is significantly related to children's development, independent of the program used. However, for future research, the authors advise examining not only the amount, but also the quality of the teacher's interaction.

Mercer and Littleton (2007), in their educational adaptation of sociocultural theory, show that high-quality classroom interaction has a positive influence on children's success in school and on their thinking. Dialogic teaching considers the interaction between teacher and children as a collective enterprise. Teacher and child participate actively in the thinking and talking. Through dialogue the participants invoke and create knowledge and understanding together (Littleton \& Mercer, 2013). This strand of theory, which is discussed in more detail in the next section, is appealing for early childhood education. For young children, play activities may offer rich opportunities for such interaction. Through communication with their teacher and peers, they make sense of the world around them. While playing, they encounter surprising situations or problems, and think up and try out solutions. For example: This sand does not stick together to build a sand castle. Now what? Or: That sand does not come out of the bottle. How come?

Teachers and educators in early childhood education and care in the Netherlands are well aware of this importance of interaction for learning. Based on educational design research, interaction courses for teachers and student teachers have been developed (Damhuis \& De Blauw, 2008; De Blauw et al., 2012). In everyday practice, however, teachers and educators still experience difficulties in realizing high-quality interaction, especially with children who are learning Dutch as a second language and children from low socio-economic backgrounds, with less rich language environments at home. A teacher participating in one of our interaction courses signalled this as an urgent practical issue: "How can I involve the low-proficient preschoolers actively and verbally in conversation?"

These signals from educational practice initiated our educational design research project. Its first aim was to develop a pedagogical approach that provoked low-proficient young children to communicate. This took us on a journey with practitioners in search for powerful elements of a teaching approach to support these children. Our second aim was to examine the interactions that practitioners realized when they implemented this approach. Does the approach help teachers to create more opportunities for active thinking and talking from the children? This aim led to two main research questions that we address in this article: 
1. How successful are teachers in changing their own role in interaction with lowproficient young children when they implement the approach?

2. How do children's contributions to the interaction change when teachers implement the approach?

We will first discuss the theoretical foundations of our research. Then we will describe the pedagogical approach that we developed. Lastly, we will present the research method and findings for the two questions, not only the initial findings, but some further explorations of the data as well. All in all, this article offers suggestions for the Canadian situation: how to realise more language- and- thought-provoking interactions with children in early childhood education, regardless of whether the context is rural, urban, Indigenous or non-Indigenous; and ways to support teachers and educators in learning to apply this approach in their own contexts.

\section{Theoretical foundations for developing the pedagogical model}

We draw on two main strands of theory and research in our project. The first concerns the role of interaction from the perspective of (second) language learning. Children need to act, think and talk actively in order to develop their language and cognitive proficiencies. It is not the case that children first learn language and then apply their learning in a conversation. Rather, through active participation in the conversations, children learn language and expand their proficiency in first language acquisition (Snow, 2014) and second language acquisition (Swain, 2005). The focus on the interaction as the crucial force in language acquisition rose from the pragmatic view on language around the notion of communicative competence (Hymes, 1972). Young children learn through communication with their parents: parents provide input that is related to the gestures and gazes of the child (semantic contingency, Cross, 1977). For children acquiring a second language, interaction is similarly crucial (Hatch, 1978).

In the context of second language learning the Input Hypothesis was introduced (Krashen, 1981): learners need comprehensible language input just a bit beyond their current level of proficiency; the context enables learners to understand such input. Soon, the Output Hypothesis was added (Swain, 1985). It stated that comprehensible input is not sufficient, but language learners also need to produce comprehensible language: they have to express their intentions in interaction with others. "Grammatical encoding is quite different in its effect from grammatical decoding, which does not push learners to reorganize their form-meaning mappings" (Swain, 2005, p. 476). Swain uses the term 'pushed output' to indicate it goes beyond mere comprehensibility: "Negotiating meaning needs to incorporate the notion of being pushed toward the delivery of a message that is not only conveyed, but that is conveyed precisely, coherently, and appropriately." (Swain, 1985, p. 248-9). Swain emphasizes that output is not to be seen as a product, but as a process: the act of producing output triggers language learning instances (Swain, 2005). She presents descriptions of, and empirical evidence for, three functions of language production for second language acquisition:

1. The noticing/triggering function. While trying to produce the target language, learners may consciously notice a linguistic problem, which triggers cognitive 
processes to solve the problem and thus create new knowledge of the language (p. 474).

2. The hypothesis testing function. Learners produce language according to their current hypothesis of how to formulate their meaning. Feedback on the production then functions as either confirmation or rejection of the hypothesis (p. 476).

3. The metalinguistic (or reflective) function. When learners use the language to reflect on the language that they or someone else have produced, it mediates language learning (p. 478).

In early childhood education and care in the Netherlands, a lot of emphasis is placed on providing ample and adequate input. To counterbalance this one-sided focus, it is important to draw the attention of teachers to the output side of language acquisition. In our work with teachers on how they may foster language and thought development of young children, we had to make several adjustments to the output hypothesis on the level of practical teaching implications:

- Swain (2005) reports that communicatively oriented classrooms and collaborative writing tasks provide more opportunities for the three output functions. The communicative orientation is very feasible in activities with young children, but it will be mainly oral communication.

- The way Swain discusses the three functions of the process of producing output involves learners who are consciously noticing, testing and reflecting on the language. For young children this will rarely be the case: they are generally focused on communication.

- The reflection in the third function is a problem-solving activity, focused on a linguistic problem: learners gain knowledge about the language. Speaking is considered "a way to complete thought" (Swain 2005, p. 479). In the second theoretical strand on which we base our work (see later on in this section), problemsolving by speaking is considered from the broader perspective of gaining knowledge about the world, e.g., science. It opens up the way to combine opportunities for language learning on the one hand, with opportunities for developing thinking proficiency on the other.

We rephrased these insights as the language learning mechanism, Figure 1, to clarify for teachers what children need for language learning. Learning in a conversation works only under the condition that the children contribute actively to the conversation and bring in their own intentions. The children themselves have to put their ideas into words. When they really want to convey their intentions, they will use the language knowledge that they presently have, even though this requires an effort. They will notice what they do not know yet: which words they miss, which sentence structure of verb inflection. This is the best moment to pay attention to the language around them. From the input and feedback they get, they will pick up the missing element and add it to their knowledge of the language. This language learning mechanism is only triggered when the child acts, thinks and talks actively. It enables the child to learn new language in natural conversations during play. 
Elaborate production at your own initiative

$=$ use present knowledge actively and creatively

Notice what you don't know yet

Pay attention to input and feedback

Discover what you need

= add to knowledge

Figure 1. Language-learning mechanism (Damhuis \& Litjens, 2003)

Example 1 makes this language learning mechanism concrete. A child and a teacher are playing with sand. The teacher has created opportunities for the child to express his thoughts and ideas. By participating actively in this conversation, he finds out what he did not know yet and adds it to his knowledge of the language and the world. It is the process of producing language that creates learning opportunities.

Example 1

\begin{tabular}{|ll|}
\hline Conversation turns & $\begin{array}{l}\text { Interpretation of what happens in the } \\
\text { turn }\end{array}$ \\
\hline $\begin{array}{l}\text { Child: That's because the sand, it-it- uh... } \\
\text { holds on to itself. }\end{array}$ & $\begin{array}{l}\text { Child expresses his ideas himself and } \\
\text { discovers he lacks the proper word. He } \\
\text { produces a circumscription 'holds on to }\end{array}$ \\
& $\begin{array}{l}\text { itself' } \\
\text { Teacher offers the appropriate word in } \\
\text { Teacher: Ah, it sticks together? }\end{array}$ \\
& $\begin{array}{l}\text { her natural response of implicit feedback } \\
\text { in the conversation }\end{array}$ \\
\hline
\end{tabular}

The second theoretical strand is learning theory in a broader sense and concerns dialogic learning and interthinking. Dialogue is considered important in education for several reasons. It functions as a learning tool: research has provided empirical support for Vygotsky's claim of the relationship between thought, language and social activity (Mercer 2008). In addition, being able to participate in dialogic learning is considered a necessary skill: it ranks high in lists of 21 st century skills. The present and future society poses an increasing need for people to work with knowledge together (Bereiter 2002, Wells, \& Claxton 2002, Binkley et al. 2010). From yet another perspective, dialogue is seen as an educational aim by itself. Dialogue is an important part of present-day cognitive development: one needs continuous dialogue to work with multiple perspectives and ultimate uncertainty (Wegerif, 2013). 
Education offers many opportunities for interthinking: collaborative thinking through talk (Littleton \& Mercer, 2013). Spoken language has a central role in interthinking, in the process of thinking collectively. However, such interthinking is rarely found in classrooms (op. cit.). Mercer and colleagues found that in classroom talk, the most enhancing form for interthinking is exploratory talk, a term coined by Barnes (see Barnes 2008). In other instances, it is indicated as productive interaction (Littleton \& Howe, 2010). Exploratory talk is described as talk in which

- everyone engages critically but constructively,

- everyone offers relevant information,

- everyone's ideas are treated as valuable,

- partners ask for reasons and give them,

- members try to reach agreement,

- reasoning is 'visible' (op. cit. p. 16).

In the settings of early childhood education and care the level of knowledge that is created often concerns the direct surroundings of the children. In the classroom a play station has been created into a bakery shop. By playing 'bakery', children learn how a client acts and talks, and what to do and say as shop owner. The teacher may join the play as a client and enrich the play with new lines of thought. For instance, after buying a bread and some cookies, she may ask for a kilo of potatoes. This starts up an exchange about what you can and cannot buy in a bakery and why that is so. Children and the teacher offer reasons with their ideas, allow each other to talk freely and accept each other's ideas. For instance, that some bakeries may have a special section with other food that they go shopping with their dad and buy bread and vegetables in the same shop that they think they could change the name of the play station shop, et cetera. Talking and thinking together deepens the knowledge of the children of the world around them.

When exploratory talk is combined with ample opportunity for pushed output, both language development and thought development will profit. Although young children's language proficiency may be low, they can express their ideas by using their current language knowledge. Even very young children can indicate relationships between object and events: they can reason. In the bakery play station, the child may say: "That one? Is more money". Teacher: "Oh, why?" Child: "Is bigger." Thus she expresses her reasoning that the apple pie the teacher-client has chosen is more expensive because it is bigger. The teacher may offer feedback that shows the more complete language structures and forms: "Oh, I see, so this one is more expensive because it is bigger." In a next series of exchanges, the teacher could provoke a similar instance for the child to apply more precise language. Teacher: "And what about this pie?" Communication is the focus here, the feedback offers the more precise language forms the child is lacking: the adjective expensive, the function word because. The opportunity for learning lies in the interaction.

Combining both strands in our project adds to the importance of creating rich dialogue in preschool and kindergarten as well as to the scope of developmental aspects that are enhanced by rich dialogue. Rich dialogue is not 'merely' required for (second) language learning, but for thinking and learning in general and for preparing children for a life in the 21 st century society. 


\section{Background: Designing our Provocative Pedagogical Approach}

Our project's aim was to develop an approach for enhancing language development and cognitive development simultaneously. We conducted an educational design study. To ensure practical feasibility as well as theoretical and educational validity, learning communities were set up of co-operating teachers and researchers. Teacher participation in the project was crucial, because teachers' personal and professional knowledge forms a valuable source for understanding what happens in education (Clandinin \& Connelly, 1996) and for improving teacher education and the success of educational innovation (Verloop, Van Driel, \& Meijer, 2001). Our project combined the practical knowledge of teachers, the theoretical findings of research and the knowledge of the researchers through intensive dialogic exchanges.

In the first phase of the project an inner circle was formed of teachers from preschool $(\mathrm{N}=9)$ and kindergarten $(\mathrm{N}=15)$ and two researchers. One learning community was based in one of the biggest cities in the Netherlands. Two preschool institutes were involved, with a total of four preschool teachers, and one primary school with seven kindergarten teachers. The pupil population showed a high percentage of L2 learners. The other learning community was in a small town in a more rural area. Three preschool institutes with a total of five teachers and three primary schools with a total of eight kindergarten teachers participated. Here the pupil population comprised a middle to high percentage of L2 learning children. All teachers were female. Approximately half of the teachers were fairly new on the job (0-4 years of experience), the others were very experienced teachers.

Working within the learning community teachers from preschool and kindergarten allowed us to learn from each other's experiences and ideas. Each learning community participated in a series of four group meetings of half a day each, with practicing periods of approximately six weeks in between. By the end of every practicing period, each teacher was individually supported in a coaching session with a researcher. The researchers led the group meetings.

The project focused on small-group activities, where a teacher joins one or two children, since these are often found to be more enhancing for language development than whole-group activities (Damhuis, 2000; Powell, Burchinal, File, \& Kontos, 2008). In the first meeting, several concrete elements (e.g., how to pose fewer questions, how to keep silent) were introduced, derived from theory and research. The teachers explored those, discussed how they could be realized in their own groups, and made a personal working plan for the next practicing period. In the last two weeks of the practicing period a researcher visited each teacher in her group and videotaped the intended interactional activity. Directly (or shortly) after the classroom visit, the researcher and teacher discussed several parts of the video in an individual coaching session.

The researchers took up issues that were raised by the participants during the group meetings and the individual coaching sessions. Ideas for tackling those issues were prepared for the next group meeting. In these meetings teachers also discussed their videos amongst each other, formulating ways in which a possible element did or did not work as expected. In this way, elements were discovered and refined gradually with which teachers felt they were able to provoke less talkative or less proficient children to communicate.

In the second phase, an outer circle was formed $(\mathrm{N}=12)$ of teachers and school leaders in the field. In a working meeting of half a day we acquainted them with the approach that 
was developed in Phase 1. Over the course of one month these participants experimented with the approach. In a second meeting they provided critical feedback.

Based on these real life practices we adjusted the approach, making sure it was feasible in a broad range of practices. The result is an approach that combines several powerful strategies in order to provoke children to act, think and talk actively.

\section{Our Pedagogical Model: A Provocative Approach}

In Figure 2 we present the 10 powerful elements for a provocative approach as a result from the work with teachers. These elements are posted on a freely-accessible website, http://www.uitdagentotgesprek.nl including explanations and illustrative video fragments.

\section{A provocative approach}

\section{Powerful practice $=$ Combine strengths}

1. Create a rich verbal learning environment

2. Join as co-player, do not ask test questions

3. Connect to the L1 life of the child

4. Create communication immediately, put into words what the child is doing

5. Create space on the speaking floor and challenge with respect to content

6. Use surprise and provocative statements

7. Give implicit feedback and continue the communication

8. Offer fixed phrases ('chunks')

9. Be less helpful: linguistically and in terms of actions

10. Create a problem

$\rightarrow$ Create opportunities \& seize opportunities

Figure 2. Ten powerful elements to provoke low-proficient children to communicate

Most of these elements are not new by themselves, as the research that informs our project has already identified them. The strength of our pedagogical model lies in the purposeful combination of these elements. Here we first discuss element 10 as a starting point. Then we present an example in which several elements are applied. We finish this section with element 4 , which addresses the alleged silent period.

Creating a problem (element 10) is powerful way to provoke children to act, think and talk actively. This works with all children, even the less talkative or less proficient ones. The preschool and kindergarten teachers in our project experienced that creating a problem works as a trigger for the other elements.

Teachers may seize an opportunity by picking up a problem that occurs spontaneously during play. This may be a very simple problem, for instance in the house play station, where two children invite the teacher to have tea with them but only two cups are on the table. The teacher exclaims "But you already drunk from these cups!" This provokes children to think, act and talk: look for another cup, or argue that it does not matter that the cups are already used. The teacher may also create a problem in line with 
the play. For instance, when a child offers the teacher 'a slice of pizza', the teacher calls out "Wow, that's too hot!" The child takes back the slice while saying "Go let it cool off a bit".

Closely connected to this element is element 9: Be less helpful. It is essential that teachers do not immediately offer a solution to a problem that occurs. The problem is meant to provoke the child to act, think and talk actively for him or herself. Teachers don't solve the problem of the heavy box by lifting it themselves, but just wait and look around encouragingly. Nor do they offer too much linguistic help. A question like "Mmm, what do we need now to lift this box?" fills in already most of the language elements that a child might have used. The child now can suffice with "a rope", a simple utterance that does not trigger the language learning mechanism. A better response by the teacher would be something quite open: "And now?" Or even a surprised "Oops!" could do the job, if followed by silence on the teacher's part.

\section{Combining Several Elements: Playing Along in the Sandbox}

Example 2 illustrates what the interaction looks like when the elements are applied. A preschool teacher and a 3-year-old girl are playing with sand and toy animals in a sandbox play station. Both are scooping up sand with their hands to fill up a ridge along the side of the box.

\section{Example 2}

\begin{tabular}{|ll|}
\hline Conversation turns & $\begin{array}{l}\text { Interpretation of what happens in the } \\
\text { turn }\end{array}$ \\
\hline 1. Child: Hey, a pig! & $\begin{array}{l}\text { Child comments on toy animal hidden in } \\
\text { the teacher's scoop of sand. }\end{array}$ \\
$\begin{array}{ll}\text { 2. Teacher: Is there a pig in it? } & \text { Child picks out the pig and sees that sand is } \\
\text { 3. Child: Hey. } & \text { leaking very slowly from the hands of } \\
& \text { teacher: surprised exclamation. } \\
& \text { Teacher first thinks there is another toy } \\
\text { animal. Then she questions what is } & \text { happening while expressing surprise using } \\
\text { one? What happens? } & \begin{array}{l}\text { facial expressions and intonation. } \\
\text { Child asks teacher to open up the crack } \\
\text { between her two hands. }\end{array} \\
\text { 5. Child: You open it. } & \text { Teacher lets sand leak slowly through. } \\
\text { 6. Teacher: Can I open it? } & \text { Child catches sand until her hands are full. } \\
\text { There it comes. (silence) } & \begin{array}{l}\text { She drops the sand on the ridge and holds } \\
\text { her hands under those of the teacher again. }\end{array} \\
\text { (silence) } & \text { But teacher has closed her hands; no sand is } \\
& \text { coming out any more. } \\
& \text { Child has to solve this problem now, by } \\
& \text { using more language. }\end{array}$ \\
&
\end{tabular}


9. Teacher: Do you want more?

Shall I open it?

10. Child: Yes.

11. Teacher: Okay, here it comes.

(silence)

12. Child: You this.

13. Teacher: We do it the other way? Open it.

14. Child: Gone.

15. Teacher: And close again.
Teacher rephrases in more complete language.

Teacher is opening and closing here hands quickly and child laughs.

Child wants to let the sand leak out of her own hands now.

Teacher rephrases and holds her hands under those of the child now.

Child closes her hands.

Teacher puts child's action into words.

Throughout this example we see element 2: the teacher joins as a co-player, follows the child in her play (line 5, line 12) and does not ask test-questions. She does not interrupt the play by asking things like "Which other animals do you see?" Element 5 is applied regularly: Create space on the speaking floor and challenge with respect to content. The teacher's contribution to the talk comprises listing responses (lines 2,9), silence after a turn (lines 6,7,11), and statements instead of questions (line 6, line 11). These contributions create opportunities for the child to take the speaking floor: to express her own ideas, by which her language learning mechanism is triggered (Damhuis, De Blauw \& Brandenbarg, 2004). The teacher also applies element 6: uses surprise (line 4) and lets the child continue. And last but not least, element 10 is put into action: the teacher creates a problem by closing her hands (after line 7).

In this short example we see instances of both creating and seizing opportunities for active acting, thinking and talking. By closing her hands and thus stopping the desired flow of sand she created an opportunity that adhered closely to the play of the child. Earlier in the example she seized the opportunity that was raised by the child's surprise in line 3 , where the child noticed that sand was trickling.

This example shows how the teacher can really play an important role in deepening play and interaction of children, in creating opportunities for active acting, thinking and talking:

- by following the play of the children - not taking control

- by communicating naturally - not asking too many questions

- by creating ample space for the children to talk - not talking herself all the time

- by creating a problem directly connected to what is happening in the play - not solving it herself

\section{Supporting Silent Children: Engage in Communication}

In our work with teachers, we paid special attention to children who appeared to be silent in preschool or kindergarten. We found that some young children entering preschool or kindergarten who were experiencing a shift in language and culture did not talk for a period of time. From a language learning point of view this may be a normal phase in the acquisition process: children are building up L2 repertoire by listening and understanding, 
before actually producing language themselves (Gibbons, 1985). Learning a new language is sometimes traumatic: it is difficult to switch between the easy-to-speak language at home, L1, and the suddenly new, unfamiliar language used in school, L2 (Granger, 2004). Silence may also be caused by other traumatic experiences and lead to psychological withdrawal (op. cit.). This is not typical for the process of language development (Gibbons, 1985). It may occur with refugee children who escaped a war in their home country, or with children who perceive the new school situation as having no connection at all with the home situation.

Teachers wondered if they should respect the silence and hope for the child to overcome this silent period soon or if that would mean missing important opportunities to support the child. They found that they could help the children by establishing communication right from the beginning. Such communication may not even need language right away. The teacher simply joins in the activity of the child, copying the action of the child. For instance, if a boy is piling up building blocks, the teacher sits next to him and also starts piling up some blocks. With facial expressions the teacher shows interest in the child's action and maybe some surprise. In this way she, the teacher, acknowledges the child and his actions and makes herself available for contact. The child and the teacher may take turns in putting another block to their pile: this turn taking in actions is already a form of communication. Now and then the teacher may add some language: she puts the ongoing action of the child into words. For instance, "Yes, you add one more block to it". Such interaction may soon elicit also some verbal contributions of the child, however short or incorrect these may be. Establishing communication thus leads to verbal interaction gradually and without pressure.

This element 4 thus encourages teachers not to comply passively with a silent period, but to actively seek means of establishing contact and non-verbal communication. Participating teachers found that this works best with an activity the child feels attracted to. They learned that it is important to find out what fascinates children, so much that she or he will forget how difficult they find the L2 and really feel the urge to make their intentions clear to the teacher. Materials that connect to the home environment play an important part: add objects from their home for instance to the house play station.

Teachers found that by applying this element they were able to create the earliest possible opportunities for active acting, thinking and talking.

\section{Research Methods}

\section{Investigating changes in interaction}

The research questions that we answer in this article concern the effects of the implementation of Provoking Active Thinking and Talking:

1. How successful are teachers in changing the interaction with low-proficient young children when they implement the approach?

2. How do children's contributions to the interaction change when teachers implement the approach?

We compared the interaction realised by teachers before the first group meeting with the interaction at the end of Phase 1, using video recordings. The teacher carried out activities 
with one or two children: before the first meeting an activity that was 'aimed at interaction', at the end of Phase 1 was another activity in which she applied the elements.

Because of time limitations we were unable to analyse all 48 videos (24 teachers with 2 videos each). Our aim here is to show that the interactional role of teachers is not a static trade, but one they can change purposefully. Therefore, we selected 12 teachers who were judged the most motivated and enthusiastic and with a variation over location and age and gender of the children. In preschool there were four teachers representing a large city and two in a small town, and at the kindergarten level, two teachers were from a large city and four represented a small town. In each video we analysed one 'target child', a total of six girls and six boys. We analysed the 'before' and 'after' videos: 24 videos in total. Table 1 shows how experienced the teachers were and some information on the children with respect to gender and whether or not they were L2 learners.

Table 1

Information about experience of teachers in analysis of change in Phase 1, and about the children

\begin{tabular}{|c|c|c|c|c|c|c|c|}
\hline $\begin{array}{l}\text { Teacher } \\
\text { code }\end{array}$ & $\begin{array}{l}\text { Teaching } \\
\text { experience }\end{array}$ & $\begin{array}{l}\text { Large } \\
\text { city }\end{array}$ & $\begin{array}{l}\text { Small } \\
\text { town }\end{array}$ & Preschool & Kindergarten & L1 & L2 \\
\hline $\mathrm{Ag}$ & 10 years & & $\mathrm{x}$ & & $\mathrm{x}$ & $\mathrm{b}$ & \\
\hline $\mathrm{Au}$ & 14 years & $\mathrm{x}$ & & & $\mathrm{X}$ & & b \\
\hline $\mathrm{D}$ & 8 years & & $\mathrm{x}$ & $\mathrm{x}$ & & & $\mathrm{g}$ \\
\hline $\mathrm{E}$ & 4 years & & $\mathrm{x}$ & $\mathrm{x}$ & & $\mathrm{g}$ & \\
\hline $\mathrm{F}$ & 3 years & & $\mathrm{x}$ & $\mathrm{x}$ & & $\mathrm{b}$ & \\
\hline $\mathrm{H}$ & 4 years & $\mathrm{x}$ & & & $\mathrm{x}$ & & $\mathrm{g}$ \\
\hline I & 2 years & $\mathrm{x}$ & & $\mathrm{x}$ & & & $\mathrm{g}$ \\
\hline $\mathrm{J}$ & 8 years & $\mathrm{x}$ & & & $\mathrm{x}$ & & $\mathrm{b}$ \\
\hline $\mathrm{L}$ & 9 years & & $\mathrm{x}$ & & $\mathrm{x}$ & & $\mathrm{b}$ \\
\hline $\mathrm{Ma}$ & 2 years & $\mathrm{x}$ & & & $\mathrm{x}$ & & g \\
\hline $\mathrm{Mi}$ & 0 years & $\mathrm{X}$ & & $\mathrm{x}$ & & & $\mathrm{b}$ \\
\hline $\mathrm{R}$ & 8 years & & $\mathrm{X}$ & $\mathrm{X}$ & & $\mathrm{g}$ & \\
\hline
\end{tabular}

(L1 = Dutch as first language; L2 = Dutch as second language; $\mathrm{b}=\mathrm{boy}, \mathrm{g}=$ girl)

Because we aimed at showing maximum changeability, we identified a "window of opportunity" (Mercer, 2009) of 10 minutes in each video. By watching the video and judging it by overall impression, we identified the span that contained the most successful interaction for linguistic and cognitive development. Such a window of opportunity is not a representative sample that shows how an average teacher usually realizes the interaction, but a sample that gives the maximum achievable quality of interaction by this teacher.

The window of opportunity of each of the 24 videos was transcribed, using each speaking turn as coding unit. A turn was considered to be everything a certain speaker said until someone else started to speak, or until someone else contributed non-verbally to the communication. The unit of analysis is a teacher and the one or two children in the filmed activity: a couple/triad.

Of the 10 elements, three were used for micro-analysis, the others for macro-analysis. In the micro-analysis we operationalized seven variables for teacher turns and seven variables for child turns. These are indicative of high-quality interaction. Table 2 shows 
the major relationships between elements and variables. There is, however, not a simple one-to-one relationship between elements, teacher variables, and child variables. For instance, speaking time of the child may be enhanced by all three elements; a decrease in teacher speaking time may lead to an increase children's speaking time, but also in increase in initiatives in turn-taking and topic, or the number of longer turns. In addition, elements in the macro-analysis may have a positive influence on the child micro-variables.

Table 2

Overview of elements, variables and expected direction of change in micro-analysis

\begin{tabular}{|lll|}
\hline Element & Teacher Variable & Child Variable \\
\hline $\begin{array}{l}\text { 2. Do not ask test } \\
\text { questions }\end{array}$ & $\bullet$ percentage of open & $\bullet$ initiative in topic $\boldsymbol{\lambda}$ \\
& questions on total number & \\
5. Create space on & $\bullet$ questions $\boldsymbol{\lambda}$ & \\
the speaking floor & $\bullet$ number of questions & $\bullet$ number of turns $\boldsymbol{\lambda}$ \\
and challenge with & $\mathbf{y}$ & $\bullet$ verbal participation \\
respect to content & $\bullet$ percentage of & $\boldsymbol{\lambda}$ \\
& question turns on total & $\bullet$ number of longer \\
& number of turns $\boldsymbol{y}$ & turns $\boldsymbol{\lambda}$ \\
& $\bullet$ number of non- & $\bullet$ initiative in turn \\
6. Use surprise and & $\bullet$ questioning turns $\boldsymbol{\lambda}$ & taking $\boldsymbol{\lambda}$ \\
provocative & $\bullet$ provocative & $\bullet$ complex cognitive \\
statements & (questions and) & language functions $\boldsymbol{\lambda}$ \\
& statements $\boldsymbol{\lambda}$ & \\
\hline
\end{tabular}

$(\boldsymbol{\lambda}=$ expected increase; $\boldsymbol{y}=$ expected decrease $)$

In the micro-analysis, each turn of the teacher was coded for every teacher variable; each child's turn for every child variable. Coding instructions were developed using a few transcripts as tryout material. Five coders were involved, working in pairs on one or more variables. Thorough discussions of codes given independently by a pair of researchers led to refining the coding instructions. After several tryouts, inter-coder reliability was assessed using 421 turns from five different transcripts. Teacher variables showed a kappa between 0.62 and 0.82 , child variables between 0.67 and 0.99 . This is considered to be a good-to-high reliability (Bakeman \& Gottman, 1986).

Frequencies of variables were standardized to 10 minutes, adjusting for some shorter videos. For the 12 teachers, one-tailed t-tests $(\mathrm{p}<0.05)$ were performed on the scores before and after applying the approach, based on the expected direction of change.

\section{Results: Initial Findings}

Teachers' interaction practices. The micro-analysis showed a significant improvement on five teacher variables when the provocative approach was applied, see Table 3. 
Table 3

Overview of significant one-tailed t-test results $(p<0.05)$ on teacher variables, with expected direction of change, means and standard deviations (. . .) per 10 minutes of the activity

\begin{tabular}{|c|c|c|c|c|c|}
\hline Teacher Variable & $\begin{array}{l}\text { Expected } \\
\text { Direction }\end{array}$ & Before & After & $\mathbf{t}(11)$ & $\begin{array}{c}p(1- \\
\text { Tailed })\end{array}$ \\
\hline $\begin{array}{l}\text { Speaking time } \\
\text { (in minutes:seconds) }\end{array}$ & $y$ & $\begin{array}{l}3: 24 \\
(1: 30)\end{array}$ & $\begin{array}{l}2: 22 \\
(0: 48)\end{array}$ & 1.93 & 0.040 \\
\hline Number of questions & $y$ & $\begin{array}{c}\mathbf{5 0 . 6 5} \\
(19.71)\end{array}$ & $\begin{array}{c}38.77 \\
(11.85)\end{array}$ & 1.89 & 0.043 \\
\hline $\begin{array}{l}\text { Percentage of question } \\
\text { turns on total number of } \\
\text { turns }\end{array}$ & $y$ & $\begin{array}{c}45.29 \\
(10.90)\end{array}$ & $\begin{array}{c}37.23 \\
(11.51)\end{array}$ & 2.10 & 0.030 \\
\hline $\begin{array}{l}\text { Number of non-questioning } \\
\text { turns }\end{array}$ & 7 & $\begin{array}{c}\mathbf{5 8 . 6} \\
(16.50)\end{array}$ & $\begin{array}{l}\mathbf{6 6 . 8} \\
(20,4)\end{array}$ & -1.94 & 0.040 \\
\hline $\begin{array}{l}\text { Percentage of open } \\
\text { questions on total questions }\end{array}$ & 7 & $\begin{array}{c}7.88 \\
(8.82)\end{array}$ & $\begin{array}{c}18.01 \\
(10.40)\end{array}$ & -2.52 & 0.014 \\
\hline
\end{tabular}

$(\boldsymbol{\pi}=$ expected increase; $\mathbf{y}=$ expected decrease $)$

The amount of speaking time a teacher used decreased, on average, from three minutes to two minutes during the 10 minutes of the activity. On average teachers asked 12 questions fewer per 10 minutes when applying the provocative approach. Note that there still remain 38 questions per 10 minutes. Within the teacher turns, the proportion of questions decreased with 8 percent points. The number of non-questioning turns increased with eight turns on average. The percentage of open questions more than doubles. Increases in provocative statements and the use of surprise did not prove statistically significant. In sum, the teachers as a group did show quite a few changes.

Children's language. Do these teacher changes concur with changes in the children's interaction after the provocative approach is applied? In contrast with the teacher results, most differences in children's variables were not statistically significant. Only the number of longer turns by children was significantly higher, as you can see in Table 4.

Table 4

Overview of significant one-tailed t-test results $(p<0.05)$ on children's variables, with expected direction of change, means and standard deviations (. . ) per 10 minutes of the activity

\begin{tabular}{|lccccc|}
\hline Children's Variable & $\begin{array}{c}\text { Expected } \\
\text { Direction }\end{array}$ & Before & After & t(11) & $\begin{array}{c}\text { p(1- } \\
\text { Tailed) }\end{array}$ \\
\hline Number of longer turns & $\boldsymbol{\lambda}$ & $\mathbf{3 . 6 6}$ & $\mathbf{1 0 . 8 3}$ & -2.380 & 0.019 \\
& & $(4.50)$ & $(8.87)$ & & \\
\hline
\end{tabular}




\begin{tabular}{|c|c|c|c|c|c|}
\hline $\begin{array}{l}\text { Longer turn of full sentence }+ \\
\text { full sentence }\end{array}$ & $\pi$ & $\begin{array}{c}\mathbf{0 . 8 9} \\
(2.43)\end{array}$ & $\begin{array}{c}\mathbf{4 . 4 5} \\
(5.48)\end{array}$ & -2.158 & 0.027 \\
\hline $\begin{array}{l}\text { Longer turn of full sentence }+ \\
\text { fragment }\end{array}$ & $\pi$ & $\begin{array}{c}\mathbf{1 . 1 6} \\
(1.54)\end{array}$ & $\begin{array}{c}3.48 \\
(3.26)\end{array}$ & -2.135 & 0.028 \\
\hline
\end{tabular}

$(\boldsymbol{\lambda}=$ expected increase; $\boldsymbol{y}=$ expected decrease $)$

The number of longer child turns almost tripled when the provocative approach was applied: from almost 4 to almost 11. It could be suggested that this is not a result of the new approach but merely a result of natural development of the children. However, we were able to rule this out by comparing older and younger children in the interaction before teachers worked with the approach: no difference was found.

Another reason why we really may attribute this difference to the provocative approach is the character of this variable. A longer turn is a turn that consists of more than one utterance. An utterance may be a fragment or a complete sentence. Longer turns contain a combination of two or more full sentences, or of a full sentence and a fragment, or of two (or more) fragments. In this way, a longer turn indicates that the children get the opportunity to express their ideas and thoughts more freely. So these turns indicate that the interaction is really different from the short question-and-answer sequences that are so typical for many conversations in education and care. And that is exactly what the provocative approach is meant to achieve.

\section{Results: Pairing Teacher and Child Variables Leads to Further Explorations}

Why did we find more significant teacher improvement of quality than children's? Were teacher changes still too small to provoke more children's participation? Indeed, when teachers still pose 38 questions per 10 minutes (i.e., 4 questions per minute), children may not yet feel free to show initiative. Children may still have the impression that the teacher is in control and that the appropriate way to participate is foremost to respond to questions, not to take initiative themselves by talking when not solicited explicitly. And when still $80 \%$ of these teachers' questions consist of closed questions, children's participation is still very often restricted. We explored patterns of change of the individual teachers in his or her small group (couple or triad) to gain more insight in the character of the changes.

Examining the number of variables where change occurred. We ranked the couples/triads according to the number of variables on which they improved in Figure 3. We see quite some variation in the number and type (teacher or children) of variables that improved.

This is consistent with our experience as teacher trainers: to change routine behaviour in interaction, teachers need to focus explicitly on the changes on the micro level. Teachers need time to build a new routine with the changed element of interaction. During Phase 1 teachers set up their personal development plan for the next period of practice with a focus on just two elements. Other elements may improve as a natural consequence, but this is not necessarily so for each and every element. Several change patterns were found. Some couples/triads changed on almost every variable (green ellipse), some on many children's 
variables (blue ellipses) or many teacher's variables (orange ellipses). One couple/triad improved on only three variables (red ellipse).

The statistically significant results (Tables 4 and 5) seemed to suggest that teachers start to work on their own interactional behaviour, and that only when they succeeded on that level would children have the opportunity to improve their participation. But in Figure 3 we have identified four couples/triads where more variables on the children's side improved than on the teacher's side. Apparently the teacher side, as represented by the micro-variables, is not a prerequisite for the intended change in interaction on the children's side. Macro-elements may play a part here (see later in this section).

All in all, Figure 3 shows that there are quite a lot of changes on the children's side, even though they are not large enough to be statistically significant.

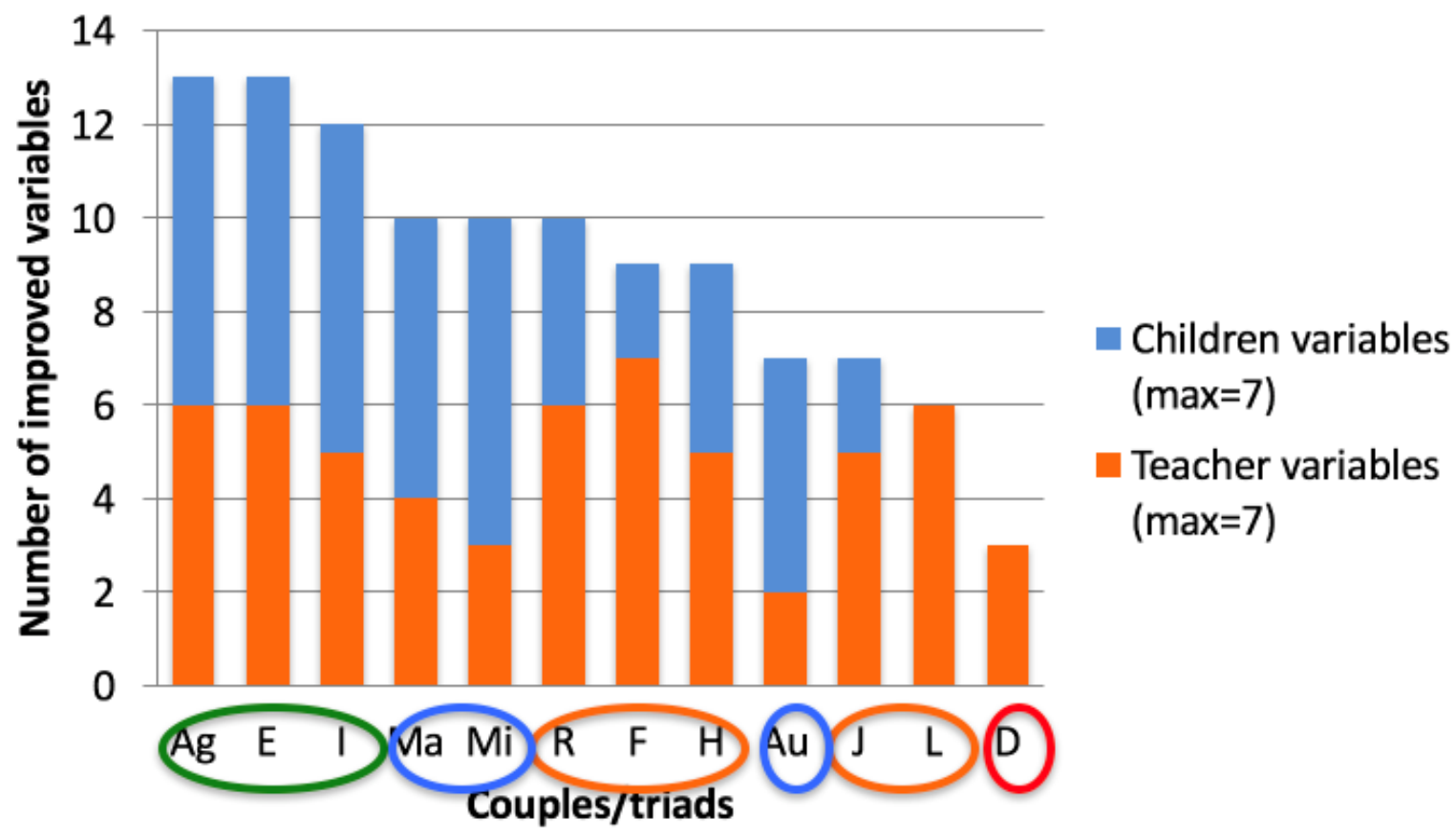

Figure 3. Number of variables on which each couple/triad improved (Ag, E, I etc. = initial of teacher)

Examining the magnitude of the changes. The next step in our exploration focused on the magnitude of the changes by individual couples/triads. Are couples/triads that change on many variables also the ones whose improvement on these variables is the largest? For instance, did teacher speaking time decrease with many minutes, or just with a few seconds? We counted per couple/triad with how many variables they belonged in the top 2 of largest improvements as per Figure 4.

In this graph we maintained the order of couples/triads according to the highest number of improved variables from Figure 3. So, the left side shows couples/triads that changed on many variables, the right side couples/triads that changed on few variables.

On the high side of the couples/triads of teachers, E and I have the most variables in the top 2 largest improvements. On the low side we find teachers $\mathrm{J}$ and D: they had no 
variables at all in the top 2. Teachers $\mathrm{E}$ and I are thus identified as high changers, and $\mathrm{J}$ and $\mathrm{D}$ as low changers.

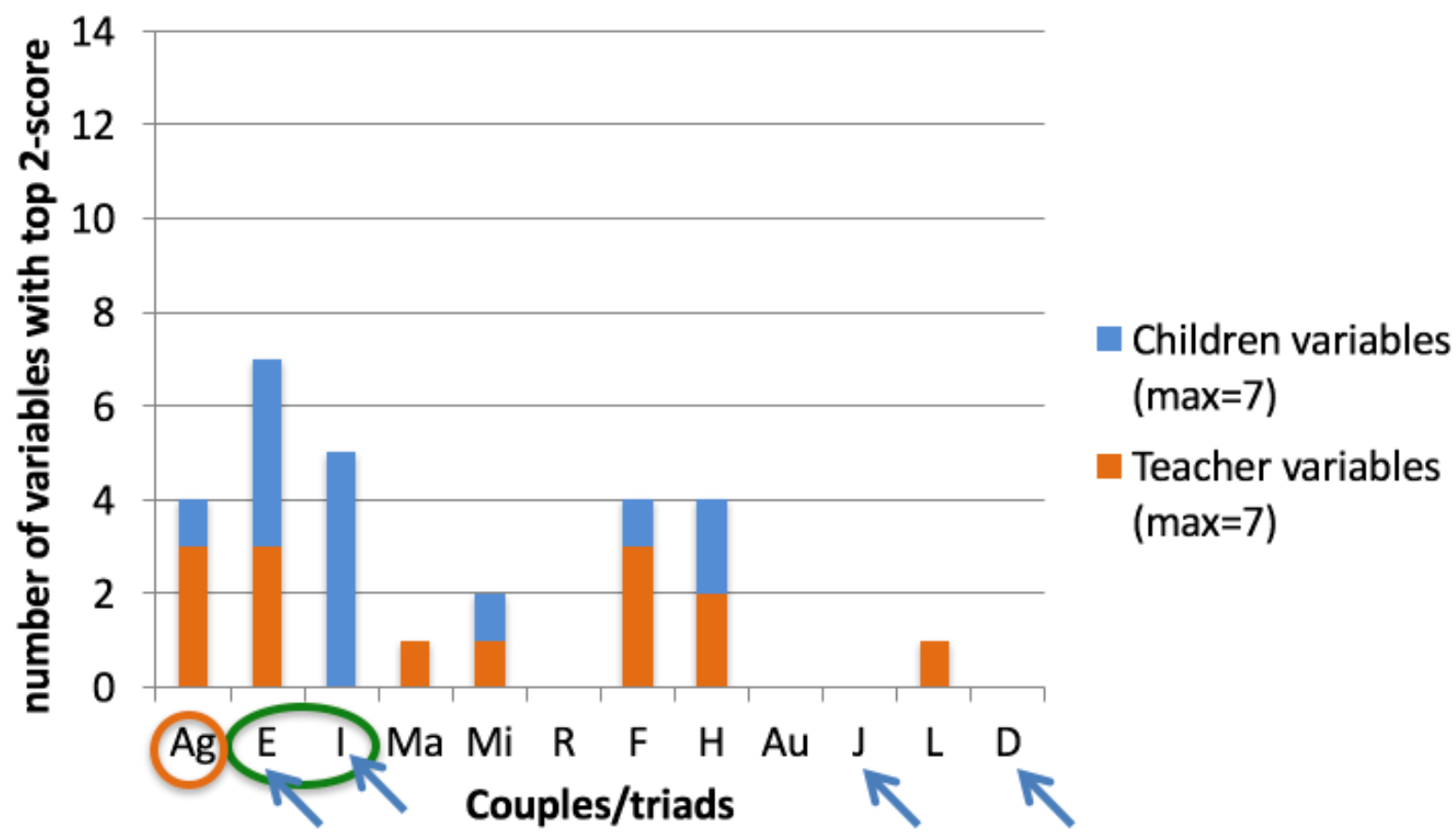

Figure 4. Number of variables on which each couple/triad belonged to the top 2 of largest changes $(\mathrm{Ag}, \mathrm{E}, \mathrm{I}$ etc. $=$ initial of teacher)

High and low changers. By examining the number of variables where changes occurred and the magnitude of the changes, we identified four teachers (refer to arrows in Figure 4). For these teachers we conducted a macro-analysis on the other elements of the provocative approach. Two researchers observed the videotapes of the activities after applying the approach and independently judged the quality on each of the macro-elements in terms of applied (+) or not applied (-). These judgements proved concurrent between the two researchers.

The high changers were found to score positive for being less helpful (element 9) and creating a problem (element 10).

Taking macro- and micro-elements both into account, the success of the high changing couples/triads lies in the combination of micro- and macro-elements. Couples/triads that improved on many variables did this on teacher micro-variables as well as on child micro-variables. Moreover, they also showed the largest improvements.

Contextualizing the results using teachers' notes. In order to find explanations for the differences in change between the couples/triads, we consulted the personal development plans of the teachers and the notes on their coaching sessions made by the trainers. In the personal development plans, teachers not only wrote down their intentions for the next practice period, but also made reflective notes after conducting the intended activities. Directly after a coaching session, trainers made notes of salient remarks that the 
teachers made. Several low change teachers indicated that they felt heavily pressed for time. They experienced the provocative approach as an activity that had to be added on top of the already full schedule of their daily program. They did not yet see how they could integrate the provocative interaction in these other activities. As a consequence, they also had less time than other teachers to practice and experiment with the approach and felt less confident with their new role. In contrast, the high changers were really able to integrate the approach in several activities of their usual program. They felt more confident in their new interaction role as well as in their possibilities of adjusting the program to their new needs while simultaneously maintaining the aims of the program.

In conclusion, from these analyses and explorations it appears essential for the provocative approach to combine elements at both the macro-and-micro level. By applying the approach, it is possible for teachers to change their interactional behaviour and to provoke children to act, think and talk actively. But not all teachers succeed to the same extent: in some couples/triads there was hardly any change. Of the 10 elements, some seem to be more powerful: e.g., be less helpful, create a problem. It requires further research to uncover more favourable and hindering factors and to discover how the several elements are interrelated.

\section{Implications for Teaching and Professional Learning Initiatives}

The core of this provocative approach is to get children to act, think and talk actively as soon as possible, and teachers are needed to provoke this. When children play freely, often a lot of such opportunities occur. Teachers can pick up these opportunities, using the elements of the provocative approach, and thus enrich the interaction without obstructing the line of play and ideas of the children. However, sometimes opportunities may not emerge spontaneously. Then the teacher needs to create them him or herself. Creating an opportunity has to be done in close connection to the interest of the children. For instance, when playing along with children in the sandbox, a teacher might pour deliberately too much water on the sand and exclaim "Oops!" This would provoke the children to think and talk about how to solve this new problem.

As our research has shown, it is possible for teachers to change their interactional behaviour in the direction of provoking more active acting, thinking and talking. However, this task is not a simple one. Teachers are asked to change their routine, to operate from a different mindset, from a different view on what constitutes high-quality interaction for language and cognitive development. That takes a lot of practice, a lot of experimenting and reflecting. Teachers deserve to be supported in that endeavour. Based on experiences of teachers and trainers in our educational design research, the following elements for an effective support are recommended:

- Create learning communities in which teachers feel safe to exchange experiences from their own real life practice and search for solutions to problems that occurred.

- Facilitate regular moments for the teacher to experiment with a small group of children.

- Use video coaching focused on the provocative approach aims of active acting, thinking and talking, and the 10 elements.

- Provide expert support in order to discover how this approach can be interwoven with the activities of the daily program. 
- Facilitate teachers to work on this change for a longer period of time, with frequent video coaching and meetings in the learning community.

Such investment in teacher support and teacher professionalization in the application of this provocative approach may yield high revenues in language and cognitive development of children across continents.

\section{References}

Bakeman, R., \& Gottman, J.M. (1986). Observing interaction: An introduction to sequential analysis. New York, NY: Cambridge University Press.

Barnes, D. (2008). Exploratory talk for learning. In: Mercer, N., \& Hodgkinson, S. (Eds.), Exploring Talk in Schools (pp. 1-15). London, England: Sage Publications Inc.

Bereiter, C. (2002). Education and Mind in the Knowledge Age. Mahwah, NJ: L. Erlbaum.

Binkley, M., Erstad, O., Herman, J., Raizen, S., Ripley, M., \& Rumble, M. (2010). Defining 21st century skills. In: P. Griffin, B. McGaw, \& E. Care (Eds.), Assessment and Teaching of 21st Century Skills (pp. 17-66). Dordrecht, Netherlands: Springer.

Clandinin, D.J., \& Connelly, F.M. (1996). Teachers' professional knowledge landscapes: teacher stories - stories of teachers - school stories - stories of schools. Educational Researcher, 25(3), 24-30.

Cross, T. (1977). Mothers' speech adjustments: the contribution of selected child listener variables. In C. E. Snow, \& C. A. Ferguson (Eds.). Talking to children: language input and acquisition (pp. 151-188). London, England: Cambridge University Press.

Damhuis, R. (2000). A Different Teacher Role in Language Arts Education: Interaction in a Small Circle with Teacher. In: J.K. Hall, \& L.S. Verplaetse (Eds.), Second and Foreign Language Learning through Classroom Interaction (pp. 243-264). Mahwah, NJ: Lawrence Erlbaum Ass.

Damhuis, R., \& Litjens, P. (2003). Mondelinge communicatie. Drie werkwijzen voor mondelinge taalontwikkeling [Oral communication. Three methods for oral language development]. Nijmegen, Netherlands: Expertisecentrum Nederlands.

Damhuis, R., De Blauw, A., \& Brandenbarg, N. (2004). CombiList, een instrument voor taalontwikkeling via interactie. Praktische vaardigheden voor leidsters en leerkrachten [CombiList, a tool for language development through interaction. Practical skills for leaders and teachers]. Nijmegen, Netherlands: Expertisecentrum Nederlands.

Damhuis, R., \& De Blauw, A. (2008). High-quality interaction in the classroom. A focus for professional learning. L1 Educational Studies in Language and Literature, 8(4), 107-126.

De Blauw, A., Damhuis, R., Sytema, S., \& Tammes, A-C. (2012). Taal en uitdagend onderwijs. Hoe we leerlingen aan het denken krijgen [Language and provocative instruction. How to get students thinking]. Internal Marnix Academie publication. 
Gibbons, J. (1985). The Silent Period: An Examination. Language Learning, 35, 255267.

Granger, C.A. (2004). Silence in Second Language Acquisition, a Psychoanalytic Reading. Clevedon, United Kingdom: Multilingual Matters Ltd.

Haan, A. de, Elbers, E., Hoofs, H., \& Leseman, P. (2013). Targeted versus mixed preschools and kindergartens: effects of class composition and teacher-managed activities on disadvantaged children's emergent academic skills. School Effectiveness and School Improvement: An International Journal of Research, Policy and Practice, 24(2), 177-194.

Hatch, E.M. (1978). Discourse analysis and second language acquisition. In: E.M. Hatch (Ed.), Second language acquisition: A book of readings (pp. 401-435). Rowley, MA: Newbury House.

Hymes, D.H. (1972). On communicative competence. In J. B. Pride, \& J. Holmes (Eds.), Sociolinguistics: selected readings (pp. 269-293). Harmondsworth, United Kingdom: Penguin. (cf. Snow, 2014).

Krashen, S.D. (1981). Second language acquisition and second language learning. Oxford, United Kingdom: Pergamon.

Littleton, K., \& Howe, C. (2010). Educational Dialogues. Understanding and promoting productive interaction. London, England: Routledge.

Littleton, K., \& Mercer, N. (2013). Interthinking. Putting Talk to Work. London, England: Routledge.

Meeuwig, M., Schepers, W., \& van der Werf, T. (2007). Sporen van Reggio, een introductie in de sporen-pedagogiek [Sporen of Reggio, an introduction to Sporen Pedagogy]. Amsterdam, Netherlands: SWP.

Mercer, N. (2008). Talk and the Development of Reasoning and Understanding. Human Development, 51, 90-100.

Mercer, N. (2009, August). What do we know about the relationship between dialogue, cognitive development and learning that is useful for education? Keynote address delivered at the EARLI Conference, Amsterdam, Netherlands.

Mercer, N., \& Littleton, K. (2007). Dialogue and the development of children's thinking: a sociocultural approach. London, England: Routledge.

OC\&W. (2013). Extra aandacht nodig voor achterstanden bij het jonge kind. Eindrapport bestandsopname voor-en-vroegschoolse educatie in Nederland [Extra attention required for disadvantages in the young child. Final stock-taking report on pre-and-early education in the Netherlands]. Den Haag, Ministerie van Onderwijs en Wetenschappen.

Powell, D.R., Burchinal, M.R., File, N., \& Kontos, S. (2008). An eco-behavioral analysis of children's engagement in urban public school preschool classrooms. Early Childhood Research Quarterly, 23, 108-123.

Snow, C.E. (2014). Input to interaction to instruction: three key shifts in the history of child language research. Journal of Child Language, 41, 117-123.

Swain, M. (1985). Communicative competence: some roles of comprehensible input and comprehensible output in its development. In S.M. Gass, \& C.G. Madden (Eds.), Input in second language acquisition (pp. 235-253). Rowley, MA: Newbury House. 
Swain, M. (1995). Three functions of output in second language learning. In G. Cook, \& B. Seidlhofer (Eds.), Principle, \& practice in applied linguistics: Studies in honor of H.G. Widdowson, 125-144. Oxford, United Kingdom: Oxford University Press.

Swain, M. (2005). The Output Hypothesis: Theory and Research. In E. Hinkel (Ed.) (2005). Handbook of Research in Second Language Teaching and Learning (pp. 471-483). Mahwah, NJ: Lawrence Earlbaum Associates.

Verloop, N., Van Driel, J., \& Meijer, P. (2001). Teacher knowledge and the knowledge base of teaching. International Journal of Educational Research, 35, 441-461.

Wegerif, R. (2013). Dialogic: Education for the Internet Age. London, England: Routledge.

Wells, G., \& Claxton, G. (2002). Learning for Life in the 21st Century. Sociocultural Perspectives on the Future of Education. Oxford, United Kingdom: Blackwell.

\section{Author Biographies}

Resi Damhuis is professor emeritus at the Marnix Academie (University for Teacher Education), in Utrecht, Netherlands and visiting researcher at the Faculty of Teacher Education of the University of Amsterdam, Netherlands. She conducts research on teachers' and early childhood educators' support of young children's language development in dramatic play settings as well as developing and conducting training courses for teachers. Contact: resi.damhuis@taaldenkgesprekken.nu

Eefje van der Zalm is a senior advisor, researcher and research project leader at the Marnix Academie (University for Teacher Education), in Utrecht, Netherlands. She conducts research on teachers' and early childhood educators' support of young children's language development in dramatic play settings. In addition, she has extensive experience in professionalization of teachers and pre-school educators. Contact:

E.vdzalm@hsmarnix.nl 